\title{
Pengaruh Skeptisme Profesional, Independensi Dan Kompleksitas Auditor Terhadap Kualitas Audit Pada Inspektorat Provinsi Sulawesi Selatan
}

\author{
Indra Gunawan $M$ \\ Email: indragunawanlahh13@gmail.com \\ ${ }^{1}$ Magister Akuntansi Pascasarjana, Universitas Muslim Indonesia \\ (Diterima: 11 Februari 2019; di revisi: 6 Maret-2019; dipublikasikan: 10 April-2019) \\ (7) (9) (C2019 -Bongaya Journal for Research Accounting STIEM Bongaya. Ini adalah artikel dengan \\ akses terbuka dibawah licenci CC BY-NC-4.0 (https://creativecommons.org/licenses/by-nc/4.0/ ).
}

\begin{abstract}
This study aims to determine and analyze the influence of professional skepticism, independence and competence of auditors on audit quality both partially and simultaneously. This study uses primary data obtained from the distribution of questionnaires. The respondents in this study were all auditors working in the Inspectorate Office of South Sulawesi Province. The results of the study show that partially the professional skepticism variable and auditor competence have a positive and significant effect on audit quality. Meanwhile, the independence variable has a negative and not significant effect on audit quality. For the results of the regression test simultaneously the variables of professional skepticism, independence, and auditor competence have a positive and significant effect on audit quality.
\end{abstract}

Keywords: Professional Skepticism; Independence; Auditor Competence; Audit Quality

\section{PENDAHULUAN}

Menurut Trisnaningsih (2010) Tuntutan terhadap terwujudnya good governance baik di sektor publik maupun swasta kini semakin gencar, dan tuntutan ini memang sangat wajar. Banyak hasil penelitian yang menunjukkan bahwa terjadinya krisis ekonomi, ternyata disebabkan oleh tata kelola yang buruk (bad governance) pada sebagian besar pelaku ekonomi (publik dan swasta). Sehingga tuntutan pelaksanaan akuntabilitas dan transparansi sektor publik terhadap terwujudnya good governance di Indonesia semakin meningkat.

Akuntabilitas dan transparansi tersebut dimaksudkan untuk memastikan bahwa pengelolaan keuangan pemerintah yang dilakukan aparatur pemerintah berjalan dengan baik (Widilestariningtyas dan Irvan, 2015).

Tentunya untuk mewujudkan pemerintah yang baik diperlukan komitmen dari semua pihak, seperti pemerintah dan masyarakat (Turangan dkk, 2016). Oleh karena itu, kepercayaan yang diberikan oleh masyarakat kepada penyelenggara pemerintahan haruslah diimbangi dengan adanya pemerintah yang bersih (Halim \& Damayanti, 2007:69).

Dikutip dalam news.detik.com (2017) Kemendagri menilai, sampai saat ini kinerja pengawasan inspektorat daerah dirasakan belum optimal. Hal itu dapat dilihat dari terdeteksinya 
masih banyak penyimpangan pengelolaan keuangan daerah dan praktik korupsi di tingkat Pemda.

$$
\text { Menurut Irjen Kemendagri Sri }
$$

Wahyuningsih dalam news.detik.com (2017) bahwa di Pemkab Klaten terjadi praktik jual beli jabatan tapi inspektorat tak mencium hal tersebut satupun. Adanya deteksi yang dilakukan oleh inspektorat di daerah belum tentu mampu mencegah adanya praktik korupsi di lingkungan Pemda. Menurutnya, hal itu menjadi gambaran lemahnya independensi inspektorat daerah.

Irjen Kemendagri Sri Wahyuningsih dalam news.detik.com (2017) menambahkan bahwa seorang inspektur yang diangkat dan diberhentikan kepala daerah dan bertanggung jawab ke kepala daerah melalui Sekda, serta eselonering di bawah Sekda mengakibatkan struktur dan kinerja inspektur menjadi tidak independen. Keterbatasan anggaran dan personel, rendahnya kapabilitas menambah permasalahan independensi pemerintah daerah.

Selain Kemendagri, KPK dalam profesionalnya dengan cermat dan seksama. Sikap skeptisisme dari auditor ini di harapkan dapat mencerminkan kemarihan profesional dari seorang auditor. Dengan sikap skeptisisme profesional auditor ini, auditor di harapkan dapat melaksanakan tugasnya sesuai dengan standar yang di tetapkan, menjunjung tinggi kaidah dan norma agar kualitas dan etika profesi auditor tetap terjaga (Gusti dan Ali, 2008).

Seorang auditor harus memiliki independensi dalam melaksanakan tugasnya. Pernyataan standar umum kedua SPKN menjelaskan bahwa "Dalam semua hal yang berkaitan dengan pekerjaan pemeriksaan, organisasi pemeriksa dan pemeriksa, harus bebas dalam sikap mental dan penampilan dari gangguan pribadi, ekstern, dan organisasi yang dapat mempengaruhi independensinya”.

Dengan kata lain bahwa setiap auditor harus mempunyai sikap independen (tidak mudah dipengaruhi) dan sikap itu harus tetap dipertahankan karena auditor seharusnya tidak memihak kepentingan siapapun dan auditor berkewajiban untuk jujur agar proses audit dapat dipercaya oleh semua pihak yang berkepentingan terutama oleh masyarakat (Karnia, 2015:6).

Selain harus mempunyai sikap skeptisisme professional dan independensi auditor juga dituntut harus memiliki kompetensi untuk menghasilkan audit yang berkualitas. Menurut Sugiarmini dan Datrini (2017), kompetensi adalah keahlian profesional seorang auditor yang didapat melalui Pendidikan formal, ujian profesional maupun keikutsertaan dalam pelatihan, seminar, simposium, dan lain-lain. Semakin tingginya pendidikan yang dimiliki oleh seorang auditor, maka akan semakin luas juga pengetahuan yang dimiliki oleh auditor (Pitaloka dan Widanaputra, 2016).

Kualitas seorang auditor dilihat dari pengetahuan tentang ilmu dan praktik audit, tingkat pelatihan, pengalaman, keterampilan umum, kemampuan mengenali dan mengindentifikasi penyimpangan, serta terus mengikuti perkembangan dalam penyusunan dan mendeteksi penyimpangan. (Mautz dan Sharaf,1986, hlm.140 dalam Mansouri, et al., 2009).

Berdasarkan latar belakang di atas, dalam penelitian ini akan membahas Pengaruh Skeptisme Profesional, Independensi, dan 
Kompetensi terhadap Kualitas Audit Pada Inspektorat Provinsi Sulawesi Selatan.

\section{TINJAUAN PUSTAKA}

\section{Teori Agency}

Menurut Suwardjono (2013:485), teori keagenan merupakan suatu teori yang menjelaskan hubungan antara pihak principal (investor) dengan agen (manajemen) dimana agen bertindak atas nama kepentingan prinsipal dan atas tindakan tersebut agen mendapatkan imbalan tertentu. Akan tetapi, Kepentingan dua pihak ini tidak selalu sejalan sehingga muncul benturan-benturan kepentingan antara keduanya apabila kedua pihak berusaha memaksimalkan utilitasnya masing-masing. Ada kemungkinan agen menyalahgunakan kepercayaan dari pemilik untuk mengambil keuntungan pribadi (Ananda, 2016).

Pihak principal termotivasi mengadakan kontrak untuk mensejahterakan dirinya dengan tingkat profitabilitas yang selalu meningkat, sedang agent termotivasi untuk memaksimalkan pemenuhan kebutuhan ekonomi dan psikologisnya antara lain dalam hal memperoleh investasi, pinjaman, maupun kontrak kompensasi. Agent mempunyai lebih banyak informasi mengenai perusahaan daripada principal sehingga dengan informasi asimetri yang dimilikinya agent dapat lebih fleksibel mempengaruhi pelaporan keuangan untuk memaksimalkan kepentingannya (Asyik, 2000).

Menurut Aljana dan Agus (2017) Jika agen tidak berbuat sesuai kepentingan principal, maka akan terjadi konflik keagenan (agency conflict), sehingga memicu biaya keagenan (agency cost). Agency problem adalah benturan kepentingan yang potensial antara prinsipal dengan agen. Dan adanya permasalahan keagenan merupakan penyebab munculnya agency cost. Agency cost adalah biaya yang muncul akibat adanya permasalahan keagenan. Oleh karena itu diperlukan adanya pihak independen yang dapat menjadi pihak penengah dalam menangani konflik tersebut yang dikenal sebagai independen auditor (Tandiontong, 2016:5).

\section{Skeptisme Profesional}

Menurut International Federation of Accountants (IFAC) skeptisisme berarti seorang auditor membuat sebuah penilaian yang kritis, dengan cara berpikir yang terus menerus bertanya dan mempertanyakan keabsahan dari bukti audit yang diperoleh dan selalu waspada terhadap bukti yang kontradiktif atau keandalan dokumen dan jawaban atas pertanyaan serta informasi lain yang dipertanyakan yang diperoleh dari manajemen dan mereka yang berwewenang sebagai pengelola (Tuanakotta, 2011:78). Skeptisisme profesional adalah kewajiban bagi auditor untuk menggunakan dan mempertahankan sikap skeptic sepanjang periode penugasan, terutama kewaspadaan akan terjadinya kecurangan (fraud) (Tuanakotta, 2013:321).

\section{Independensi}

Mulyadi (2002:26) mengatakan bahwa independensi berarti sikap mental yang bebas dari pengaruh, tidak dikendalikan oleh pihak lain, tidak tergantung pada orang lain. Independensi juga berarti adanya pertimbangan yang objektif dalam merumuskan dan menyatakan pendapatnya. Hal ini mengharuskan auditor tidak boleh berpihak dengan siapapun 
dan dapat menghadapi tekanan apa pun dari klien sehingga auditor harus memiliki sikap independensi dalam menjalankan tugasnya dalam melakukan audit (Pitaloka dan Widanaputra, 2016).

\section{Kompetensi Auditor}

Menurut Siti Kurnia Rahayu dan Ely Suhayati (2010:2) mendefinisikan kompetensi adalah suatu kemampuan, keahlian (pendidikan dan pelatihan), dan berpengalaman dalam memahami kriteria dan dalam menentukan jumlah bahan bukti yang dibutuhkan untuk dapat mendukung kesimpulan yang akan diambilnya. Menurut Apriliyani dkk (2013) keahlian yang harus dikuasai oleh auditor adalah akuntansi, statistika,komputasi, ekonomika, hukum, manajemen, dan kebijakan publik.

\section{Kualitas Audit}

Dalam sektor publik, Government Accountability Office (GOA) mendefinisikan kualitas audit sebagai ketaatan terhadap standar profesi dan ikatan kontrak selama melaksanakan audit. Standar audit menjadi bimbingan dan ukuran kualitas audit yang dilakukan oleh auditor pemerintah itu sendiri (Ananda, 2014).

\section{Hipotesis}

$\mathrm{H}_{1:}$ Skeptisme profesional berpengaruh terhadap Kualitas Audit

$\mathrm{H}_{2}$ : Independensi berpengaruh terhadap Kualitas Audit

$\mathrm{H}_{3}$ : Kompetensi auditor berpengaruh terhadap Kualitas Audit

$\mathrm{H}_{4}$ : Skeptisme Profesional, Independensi, dan Kompetensi Auditor berpengaruh secara simultan terhadap Kualitas Audit
Jenis, Sumber dan Teknik Pengumpulan Data

Jenis data yang digunakan dalam penelitian ini adalah data kuantitatif dengan sumber data terdiri dari data primer dan data sekunder. Data primer berupa kuesioner yang diperoleh secara langsung dari responden dan data sekunder yang diperoleh dari Kantor Inspektorat Provinsi Sulawesi Selatan mengenai jumlah auditor yang bekerja maupun dari internet yang berguna untuk memberikan informasi tambahan yang menyangkut dengan penelitian ini. Adapun teknik pengumpulan data yang digunakan dalam penelitian ini adalah dengan membagikan kuesioner kepada auditor yang bekerja di kantor Inspektorat Provinsi Sulawesi Selatan.

\section{Populasi Penelitian}

Populasi dalam penelitian ini adalah auditor di Inspektorat Provinsi Sulawesi Selatan. Berdasarkan data yang diperoleh, jumlah auditor yang ada di Inspektorat sebanyak 46 orang. Berdasarkan data tersebut, maka seluruh auditor yang bekerja di kantor Inspektorat Provinsi Sulawesi Selatan dapat digunakan sebagai responden. Menurut Sugiyono, (2013:122) sampling jenuh adalah teknik penentuan sampel bila semua anggota populasi di gunakan sebagai sampel.

\section{Operasionalisasi Variabel}

Operasionalisasi variabel dimaksudkan untuk membedakan variabel terikat (dependen variabel) dan variabel bebas (independen variabel) dari sub variabel serta menjelaskan indikator dari masing-masing variabel penelitian dan untuk mengukurnya menggunakan Skala Likert. 
Berikut ini akan dijelaskan mengenai definisi operesional variabel yang digunakan dalam penelitian ini:

Skeptisme Profesional (X1) merupakan sikap yang selalu mempertanyakan dan melakukan evaluasi bukti audit secara kritis. Instrumen yang digunakan adalah kuesioner yang diukur dengan menggunakan tiga indikator yaitu : Questioning Mind, Suspension of Judgment, dan Interpersonal Understanding.

Independensi $\left(\mathrm{X}_{2}\right)$. Pada umumnya independensi merupakan sifat seorang auditor yang tidak dapat dipengaruhi oleh siapapun dalam melaksanakan pekerjaannya sebagai seorang auditor dalam mengaudit laporan keuangan untuk kepentingan umum. Instrumen yang digunakan adalah kuesioner yang diukur dengan menggunakan tiga indikator yaitu : Independensi penyusunan program, Independensi pelaksanaan pekerjaan, dan Independensi pelaporan.

Kompetensi $\left(\mathrm{X}_{3}\right)$ dalam pengauditan merupakan pengetahuan, keahlian, dan pengalaman yang dibutuhkan auditor untuk dapat melakukan audit secara obyektif, cermat,dan seksama. Instrumen yang digunakan adalah kuesioner yang diukur dengan menggunakan tiga indikator yaitu : Mutu Personal, Pengetahuan Umum, dan Keahlian Khusus.

Kualitas Audit (Y) merupakan suatu laporan audit yang mana laporan keuangan tersebut harus sesuai dengan prinsip akuntansi berterima umum. Jika auditor dapat melaksanakan pekerjaannnya secara profesional maka laporan audit yang dihasilkan akan berkualitas. Instrumen yang digunakan adalah kuesioner yang diukur dengan menggunakan dua indikator yaitu : Kesesuaian Pemeriksaan dengan Standar Audit dan Kualitas laporan hasil pemeriksaan.

\section{Metode Analisis}

Teknik analisis yang dipakai dalam penelitian ini dimulai dengan menguji kesahihan alat ukur (instrumen). Kesahihan alat ukur penelitan ditentukan dengan menguji instrumen penelitian yang meliputi uji validitas dan reliabilitas. Selanjutnya sebelum dilakukan pengujian hipotesis dilakukan uji asumsi klasik yang meliputi uji normalitas, heterokedasitas dan multikolinearitas. Tujuannya adalah untuk menghasilkan paramereter yang baik sehingga hasil penelitian dapat diandalkan. Semua pengujian dilakukan dengan program komputer SPPS versi 23. Sedangkan, untuk melihat pengaruh dari variabel-variabel independen (skeptisme profesional, independensi dan kompetensi auditor) terhadap variabel dependen (kualitas audit) digunakan uji regresi berganda. Dengan persamaan sebagai berikut:

$$
\begin{array}{ll}
\mathrm{Y}=\mathrm{a}+\mathrm{b}_{1} \mathrm{X}_{1}+\mathrm{b}_{2} \mathrm{X}_{2}+\mathrm{b}_{3} \mathrm{X}_{3}+€ \\
\mathrm{Y} & =\text { Kualitas Audit } \\
\mathrm{a} & =\text { Konstanta } \\
\mathrm{b}_{1}, \mathrm{~b}_{2}, \mathrm{~b}_{3} & =\text { Koefisien Regresi } \\
\mathrm{X}_{1} & =\text { Skeptisme Profesional } \\
\mathrm{X}_{2} & =\text { Independensi } \\
\mathrm{X}_{3} & =\text { Kompetensi Auditor } \\
€ & =\text { Batas Kesalahan }
\end{array}
$$

\section{HASIL DAN PEMBAHASAN}

Setelah hasil uji asumsi klasik dilakukan dan hasilnya secara keseluruhan menunjukkan model regresi memenuhi asumsi klasik, maka tahap berikut adalah melakukan evaluasi dan interpretasi model regresi berganda. Analisis 
regresi linear berganda digunakan untuk mengetahui pengaruh antara variabel independen terhadap variabel dependen, berikut disajikan tabel 1 yang merupakan hasil uji regresi linear berganda sebagai berikut :

Tabel 1

Hasil Perhitungan Regresi Berganda

\begin{tabular}{|c|c|c|c|c|c|c|}
\hline \multirow{2}{*}{ No. } & \multirow{2}{*}{$\begin{array}{c}\text { Variabel } \\
\text { Independen }\end{array}$} & \multirow{2}{*}{\begin{tabular}{|c|} 
Koefisien \\
Regresi
\end{tabular}} & \multirow{2}{*}{ t-hitung } & \multirow{2}{*}{ Sig. } & \multicolumn{2}{|c|}{ Korelasi } \\
\hline & & & & & r-parsial & $\mathrm{Sig}$ \\
\hline 1. & $\mathrm{X}_{1}$ & 0,208 & 1,279 & 0,208 & 0,270 & .040 \\
\hline 2. & $\mathrm{X}_{2}$ & $-0,139$ & $-1,161$ & 0,253 & $-0,021$ & .446 \\
\hline 3. & $\mathrm{X}_{3}$ & 0,661 & 5.079 & 0,000 & 0,638 & .000 \\
\hline $\begin{array}{l}\text { Konsta } \\
\text { Multipl } \\
\text { F hitung } \\
\end{array}$ & $\begin{aligned} & =1.148 \\
R & =0,667 \\
& =10,414\end{aligned}$ & $\begin{array}{l}\mathrm{RS} \\
\mathrm{Sig} \\
a \\
\end{array}$ & & $\begin{array}{l}=0,445 \\
=0,000 \\
=0,05\end{array}$ & & \\
\hline
\end{tabular}

Sumber: Data diolah, 2019

Tabel di atas menunjukkan bahwa koefisien korelasi (Multiple $R$ ) bertujuan untuk mengetahui derajat atau tingkat keeratan hubungan antara keseluruhan variabel independen. Nilai koefisien korelasi (R) dalam penelitian ini sebesar 0,667 atau $66,7 \%$ yang berarti bahwa hubungan korelasi antara variabel independen (skeptisme profesional, independensi dan kompetensi auditor) terhadap variabel dependen (kualitas audit) adalah sebesar 0,667 atau $66,7 \%$. Berdasarkan pedoman untuk memberikan interpretasi koefisien korelasi Sugiyono (2014:250), maka dapat disimpulkan bahwa keeratan hubungan variabel kompleksitas tugas, etika auditor, dan risiko audit terhadap kualitas adalah kuat.

Besarnya pengaruh variabel independen secara keseluruhan ditunjukkan oleh nilai adjusted $\mathrm{R}$ square yaitu sebesar 0,445 . Hal ini berarti bahwa ketiga variabel independen tersebut mempunyai pengaruh sebesar $44,5 \%$ terhadap kualitas audit sedangkan sisanya sebesar 55,5\% (100\%-44,5\%) dipengaruhi oleh variabel lain yang tidak disertakan dalam penelitian ini.

Berikut adalah hasil penelitian untuk masing-masing variabel melalui uji statistik $F$ dan uji statistik $\mathrm{T}$ yang akan dijelaskan dalam pembahasan dibawah ini :

\section{Pengaruh Skeptisme Profesional Terhadap Kualitas Audit}

Untuk variabel skeptisme profesional $\left(\mathrm{X}_{1}\right)$ diperoleh nilai $\mathrm{t}_{\text {hitung }}$ sebesar $-1,279<\mathrm{t}_{\text {tabel }}$ sebesar 1,685 dan tingkat signifikansinya lebih besar dari taraf kepercayaan sebesar $5 \%$ yaitu $0,208>0,05$. Tetapi dilihat dari sisi korelasi, koefisien korelasinya 0.270 dan level signifikansinya $0.040<0.050$. Sehubungan dengan itu, hasil analisis regresi menunjukkan bahwa secara parsial variabel skeptisme profesional $\left(\mathrm{X}_{1}\right)$ berpengaruh positif dan tidak siginifikan terhadap kualitas audit (Y) sehingga hipotesis pertama pada penelitian ini ditolak. Tetapi dilihat dari hasil analisis korelasi, variabel skeptisme profesional $\left(\mathrm{X}_{1}\right)$ berpengaruh positif dan siginifikan terhadap kualitas audit (Y) sehingga hipotesis pertama pada penelitian ini diterima. Dalam penelitian ini, peneliti menerima hasil analisis korelasi bahwa hipotesis pertama ini diterima.

Dengan memperhatikan data hasil penelitian pada Inspektorat Provinsi Sulawesi Tengah, dapat dikatakan bahwa implikasi pentingnya skeptisme profesional telah diterapkan. Dalam melakukan pemeriksaan auditor diperhadapkan pada situasi antara curiga dan percaya terhadap auditee. Tetapi auditor profesional tidak akan pernah berpikir bahwa auditee tidak jujur tapi auditor juga tidak dapat 
mengasumsikan bahwa auditee sepenuhnya jujur. Menolak statement tanpa ada pembuktian merupakan bukti bahwa auditor Inspektorat memiliki questioning mind yang tinggi atau pikiran selalu mepertanyakan sesuatu yang menjadi salah satu indikator dalam penelitian ini.

\section{Pengaruh Independensi Terhadap Kualitas} Audit

Untuk variabel independensi $\left(\mathrm{X}_{2}\right)$ diperoleh nilai $\mathrm{t}_{\text {hitung }}$ sebesar $-1,161<\mathrm{t}_{\text {tabel }}$ sebesar 1,685 dan tingkat signifikansinya lebih besar dari taraf kepercayaan $5 \%$ yaitu $0,253>0,05$. Dari sisi analisis korelasi dijumpai hasil yang sejalan, yaitu memiliki koefisien yang bertanda matematik negatif serta level signifikansinya $0.446>0.05$. Dengan demikian nilai ini menunjukkan bahwa secara parsial variabel independensi $\left(\mathrm{X}_{2}\right)$ berpengaruh negatif dan tidak signifikan terhadap kualitas audit (Y). sehingga hipotesis kedua pada penelitian ini ditolak.

Menurut Anggoro (2015) dikutip dalam kompas, mengatakan selama ini, inspektorat hanya bawahan Menteri/kepala Lembaga dan kepala daerah. Dalam kondisi itu, tidak jarang peringatan yang dikeluarkan inspektorat diabaikan begitu saja. Bahkan bisa jadi lebih buruk, tak sekedar diabaikan, mereka yang memperingatkan kerap dianggap sebagai musuh dalam selimut Sanksinya, bisa saja dibebastugaskan, dimutasi, atau kariernya dipersulit. Sehingga hal tersebut berdampak pada independensi yang di miliki oleh pihak inspektorat, kama ketika pihak auditor menjadi sangat independen dalam merumuskan dan menyampaikan pendapat mereka, muncul intervensi dari pihak lain yang membuat auditor tidak bisa independen. Sehingga berdasarkan asumsi tersebut, inilah yang menyebabkan independensi memiliki pengaruh yang negatif terhadap kualitas audit yang dihasilkan oleh inspektorat provinsi Sulawesi Selatan.

\section{Pengaruh Kompetensi Auditor Terhadap}

Kualitas Audit

Untuk variabel kompetensi audit $\left(\mathrm{X}_{3}\right)$ diperoleh nilai $t_{\text {hitung }}$ sebesar $5.079>t_{\text {tabel }}$ sebesar 1,685 dan tingkat signifikansinya lebih kecil dari taraf kepercayaan $5 \%$ yaitu $0,000<0,05$. Dari sisi analisis korelasi, diperoleh hasil yang sejalan, yaitu koefisien korelasi positif dan level signifikansinya $0.000<0.05$. Dengan demikian nilai ini menunjukkan bahwa secara parsial variabel Kompetensi $\left(\mathrm{X}_{3}\right)$ berpengaruh positif dan signifikan terhadap kualitas audit (Y). sehingga hipotesis ketiga pada penelitian ini diterima.

Dengan melihat hasil penelitian ini maka bisa dikatakan kompetensi membantu auditor dalam menyelesaikan audit secara efektif. Semakin tinggi kompetensi seorang auditor maka akan semakin tinggi pula kualitas audit yang dihasilkannya.

\section{Pengaruh Kompleksitas Tugas, Etika Auditor} dan Risiko Audit Terhadap Kualitas Audit

Uji F digunakan untuk menguji pengaruh secara simultan antara seluruh variabel independen $\left(\mathrm{X}_{\mathrm{i}}\right)$ dengan variabel dependen $(\mathrm{Y})$ yang diteliti. Berdasarkan hasil uji ANOVA (Analysis of Varians) atau $\mathrm{F}$ test (lampiran VI) diperoleh nilai $F_{\text {hitung }}$ sebesar 10,414 $>F_{\text {tabel }}$ sebesar 2,85 dan tingkat signifikansi lebih kecil dari taraf ketidakpercayaan $5 \%(0,000<0,05)$. Hasil tersebut berarti bahwa secara simultan (bersama-sama) variabel $\mathrm{X}_{1} \quad$ (skeptisme profesional, independensi, dan kompetensi audit) 
berpengaruh positif dan signifikan terhadap variabel Y (Kualitas Audit). Oleh karena itu, hipotesis keempat dapat diterima.

\section{KESIMPULAN DAN SARAN}

Berdasarkan hasil analisis dan pembahasan, maka kesimpulan penelitian ini sebagai berikut:

1. Secara simultan skeptisme profesional, independensi, dan kompetensi audit berpengaruh positif dan signifikan terhadap kualitas audit. Hal ini dapat diartikan bahwa semakin kompeten dan profesional auditor maka akan semakin baik kualitas laporan hasil audit.

2. Secara parsial independensi berpengaruh negatif dan tidak signifikan terhadap kualitas audit. Sedangkan kompetensi dan skeptisme professional berpengaruh positif dan signifikan terhadap kualitas audit.

Berdasarkan kesimpulan penelitian yang telah diuraikan sebelumnya, maka saran peneliti adalah sebagai berikut:

1. Untuk meningkatkan kualitas audit yang ada pada auditor Inspektorat Provinsi Sulawesi Selatan, hendaknya para auditor lebih peka lagi terhadap setiap tindakan yang dilakukan oleh klien.

2. Kepada pimpinan auditor hendaknya tidak memberikan intervensi kepeda para auditor dalam menyusun program audit

3. Auditor Inspektorat Provinsi Sulawesi Selatan hendaknya lebih berhati-hati dalam memberikan setiap solusi kepada kliennya. Serta temuan yang berupa perkiraan dan asumsi harus didukung dengan data dan bukti yang kuat.
4. Berdasarkan nilai adjusted R Square sebesar 0,423 maka masih terdapat variabel independen lain yang dapat diduga berpengaruh terhadap kualitas audit sehingga dapat mendorong peneliti selanjutnya untuk mencari variabel lain yang diduga dapat mempengaruhi kualitas audit, misalnya; akuntabilitas, etika audit maupun kecermatan professional (due professional care).

\section{DAFTAR RUJUKAN}

Ananda Rahmatika. 2014. Pengaruh Skeptisme Profesional, Kepatuhan Pada Kode Etik dan Independensi Terhadap Kualitas Audit (Studi Empiris pada BPKP perwakilan Sumatera Utara). Artikel, Univesitas Negeri Padang. Hal: 3-5.

Apriliyani Ika Berty, Rita Anugerah \& Poppy Nurmayanti. 2013. Faktor-Faktor Yang Mempengaruhi Kualitas Audit Apip Pada Inspektorat Provinsi Riau. Pekbis Jurnal, Vol.5, No.3, November. 145-158

Gusti, Maghfirah dan Syahril Ali. 2008. "Hubungan Skeptisisme Profesional Auditor Dan Situasi Audit, Etika, Pengalaman Serta Keahlian Audit Dengan Ketepatan Pemberian Opini Auditor Oleh Akuntan Publik". Simposium Nasional Akuntansi XI, Padang. Hal : 3-6.

Karnia Nolanda Dwi. 2015. Pengaruh Kompetensi, Independensi, Motivasi, dan Akuntabilitas Terhadap Kualitas Audit (Studi Empiris Pada Aparat Inspektorat Provinsi Jawa Tengah). Skripsi Universitas Diponegoro Semarang.

Mansouri, Ali, Reza Pirayesh dan Mahdi Salehi. 2009. Audit Competence and Audit Quality: Case in Emerging Economy. International Journal of Business and Management. Vol.4 No.2: 17-25.

Mulyadi, 2002, Auditing, Edisi keenam, Cetakan pertama, Jakarta: Salemba Empat.

Pitaloka Yuli Dan A.A.G.P Widanaputra. 2016. Integritas Auditor Sebagai Pemoderasi Pengaruh Kompetensi dan Independensi 
Pada Kualitas Audit. E-Jurnal Akuntansi Universitas Udayana Vol.16.2. Agustus (2016). ISSN: 2302-8556, Hal: 1574-1603.

Putro Galang Aji. 2017. Kemendagri Soroti Kinerja Lemah Inspektorat Pantau Penyimpangan, (Online). (https://news.detik.com/berita/d3404983/kemendagrisoroti-kinerja-lemah-inspektorat-pantau penyimpangan. Diakses Rabu 25 Januari 2017).

Sugiyono. 2013. Metode Penelitian Bisnis. Bandung: Alfabeta

Suwardjono. 2013. Teori Akuntansi Perekayasaan Pelaporan Keuangan. Yogyakarta: BPFE-Yogyakarta

Trisnaningsih, Sri. Januari 2010. Paradigma Baru Profesi Akuntan dalam mewujudkan Good Governance dan Tantangan Masa Depan, 1.

Tuanakotta, Theodorus M. 2013. "Audit Berbasis ISA”. Jakarta : Penerbit Salemba Empat.

Turangan Feibe Maria, David Paul .E. Saerang, dan Jullie. J. Sondakh. 2016. Pengaruh Skeptisisme Profesional, Kompetensi, dan Independensi Auditor terhadap Kualitas Pemeriksaan dalam Pengawasan Keuangan Daerah dengan Kepatuhan Pada Kode Etik Sebagai Variabel Moderating. Goodwill Journal of Accounting and Auditing Research. Hal : 71. 